\title{
Are major German Companies leading the sustainability path?
}

\author{
Viele Firmen haben begonnen, sich mit dem \\ Thema Nachhaltigkeit zu beschäftigen, um \\ den Erwartungen der Gesellschaft gerecht zu \\ werden. Dieser Artikel untersucht die Indikato- \\ ren zur Messung von Nachhaltigkeit, die die \\ zwanzig größten Deutschen Firmen in ihren \\ Selbstdarstellungen verwenden. \\ Von Francisco Székely und Marianna Knirsch
}

$\mathrm{M}$ any large and midsize companies have started to incorporate sustainability into their business strategies. However, these initiatives are reported on in ways that are difficult to understand and compare. There is a need to establish clear and user-friendly methodologies and tools to measure the progress that companies are making towards sustainability. Companies are increasingly being asked to provide more and better information on how they identify and manage social and environmental issues. They are also being asked to explain how these opportunities and threats affect short- and long-term value. Standard measuring procedures are needed to make possible greater comparability of sustainability policies and to enable the companies themselves to set and adapt targets and to develop standards for internal benchmarking and year-on-year progress. Companies can focus on the future and report on future sustainability plans in addition to providing historical data on past activities.

\section{The development of sustainability measurement}

Companies have long tried to measure elements of sustainability including various resource uses that carry economic costs as well as certain emissions and wastes as mandated by regulation. In 1998, John Elkingtom, chairman of SustainAbility, institutionalized the concept of the triple bottom line. He presented the view that the 21st century business needs to focus on enhancing environmental quality and social equity in the same time and with the same effort as striving for profits thus weighing the three sustainability spheres equally.

Canada's National Round Table on the Environment and the Economy (NRTEE) conducted one of the earliest studies in the development of sustainability metrics. Their search for a small set of eco-efficiency indicators that is meaningful and applicable across industries became an underlying theme in the later efforts to develop sustainability metrics. The World Business Council for Sustainable Development (WBCSD) continued work in the same direction. In addition to the material and energy consumptions, they recognized water consumption as another important eco-efficiency metric. Another early effort in developing sustainability metrics was undertaken by the Center for Waste Reduction Technologies (CWRT) of the American Institute of Chemical Engineers (AIChE). Representatives from CWRT member companies concluded on a set of basic and complementary sustainability metrics expressed on a choice of denominators that include mass, revenue, and value added.

There are various approaches that have been used to measure, monitor and assess a company's progress towards sustainability. They include surveys, award schemes, investor's criteria, benchmarking, sustainability indexes and indicators, external communication tools, accreditation processes, standards and codes, metrics for sustainability performance, and non-quantifiable sustainability initiatives. The challenge in developing sustainability metrics or indicators lies in organizing the information in a format that best supports decision-making in terms of sustainability. Following is a brief discussion of the last two approaches (Tanzil/Ma/Beloff 2003).

\section{Metrics for sustainability performance}

Sustainability metrics and indicators assist in the assessment of the progress a company has made in promoting sustainable development internally and externally in a given time period. They are usually expressed as ratios. The numerator includes impacts such as resource consumption, pollution effects, and land use. The denominator contains measures of desired outputs such as production and economic or social value added. Thus, the metrics follow a simple rule of thumb: the lesser the metric, the better. The metrics can be designed to be both scalable for different boundaries, for example a business unit, and stackable along the supply chain.

Economic sustainability metrics: Annual corporate reports primarily address the immediate needs of shareholders and financial analysts but do not directly address what is important to stakeholders in economic as opposed to purely financial terms (Jennings/ Vernon 2004). Nor do financial reports detail the wider economic impacts of the activities of a company as an employer on community level. The company's impact on local suppliers and service providers also goes unexamined. Information on the wider economic impact of a company requires quantitative measurement of operational outcome. 
Environmental sustainability metrics: It is important to identify those aspects of business that have the greatest actual or potential impact on the environment and the organization. Large organizations with multiple facilities require consistent environmental indicators across similar operations for comparability. At the same time, facilities require flexibility to establish environmental indicators that are unique to their own operations, location, regulations and surroundings.

The ecological footprint is a tool for measuring and analyzing human natural resource consumption and waste output within the context of nature's renewable and regenerative capacity. It represents a quantitative assessment of the biologically productive area or the amount of nature required to produce resources and to absorb the wastes of an individual person, city, region or country. Footprints are not bad or good per se. Every living entity possesses an ecological footprint; it is the size that varies. On a global scale, humanity's entire ecological footprint can be compared to the total available natural capital and services. When humanity's footprint is within the annual regenerative capabilities of nature, its footprint is sustainable. From the footprint perspective, sustainability requires human beings to live within the regenerative and absorptive capacity of the planet. The corollary in the biological sciences is typically referred to as a sustainable yield. The ecological footprint does not address triple bottom line sustainability as it only concentrates on environmental sustainability.

Social sustainability metrics: Efforts to measure and manage social performance strategically are still evolving, and companies are looking for meaningful and realistic ways to measure and report on social performance.

Integrated sustainability metrics: Two classes of metrics or indicators are used to indicate the state and performance of a system. Those that indicate the state of a system are known as content indicators and those that measure the behavior of a system as performance indicators. Naturally, researchers have attempted to measure improvements in terms of three groups of metrics corresponding to the three aspects of sustainability: ecological metrics, economic metrics and sociological metrics. These metrics measure only one aspect of the system and are therefore one-dimensional.

Despite enormous efforts to translate economic, environmental and social performance indicators into measures of financial value, many sustainability indicators are qualitative in nature and do not lend themselves well to financial valuation. The outcome of sustainability strategies and the corresponding capital outlays are uncertain and benefits often difficult to forecast.

\section{Major German companies}

The European School of Management and Technology Berlin has conducted a one-year study examining in detail how 20 major German companies measure sustainability. Many companies are reporting about sustainability as a public relations strategy. Few are considering sustainability as an integral part of their business strategy and are measuring economic, environmental, and social performance in order to achieve sustainability goals and targets. When compared with other major European large multinationals some German companies seem to be leading the path to sustainability since they are making a real effort to integrate the three dimensions of sustainability. The seven companies who represented more leadership on developing and using metrics for sustainability in Germany include Allianz, Axel Springer, Deutsche Telekom, RWE, Volkswagen, Siemens and Schering.

The analysis of the sustainability reports and the related websites of the sample companies reveal large differences in what and how the companies measure their sustainability performance, and how they report on it. Ten out of the twenty companies analyzed, report in accordance with the guidelines of the Global Reporting Initiative (GRI), but the scope and range of what is measured and reported on varies. Following is an overview of economic, environmental, social and integrated indicators, used by these companies.

Although there is mutual agreement on economic metrics, which are primarily derived from the companies' annual reports, no connection is made between the economic performance and the implications for sustainability. Only few of the analyzed companies indicate the equivalent monetary value of all benefits to staff and the taxes paid to all tax-levying authorities as indicators of economic impact. In dealing with the economic impact of business on employment and taxation, the company can emphasize the sustainability side of economic performance that strategically connects economic performance and sustainability. Economic metrics are based on international reporting practices of economic performance and have the following characteristics:

- Company wide

- Collected annually and quarterly

- Audited externally

- Comparable internally and externally

- User-friendly and meaningful

- Connected to future performance targets

Environmental metrics: Measuring and reporting on environmental performance has a long tradition in Germany. Most companies began by producing environment, health and safety (EHS) reports. There does not exist agreement on what needs to be reported on. The data provided by the companies only relates to unwanted emissions in the environment (waste, air and water pollution) and energy consumption. Little or no information is provided on the consumption of other natural resources or on how the reported emissions and consumed resources impact the environment and natural ecosystems. Comparability between companies is limited due to differing measurement categories. In order to allow benchmarking and highlight longterm risks and opportunities, the information measured needs a standard format and references to make it truly comparable. Environmental metrics need to fulfill most of the criteria that economic sustainability metrics meet. 
Social metrics: In the majority of the companies analyzed, the measurement of social sustainability is confined to employee numbers, percentage of female employees, accident numbers and training or apprentices' figures. Though measuring similar human resource-related issues, the companies are difficult to compare since the terms of the references differ. Only a few broader social metrics come into play and these vary from company to company, thus making meaningful analysis and comparison impossible with the exception of donations and sponsoring. There is a need to develop and establish a quantitative framework to present data that can be measured and compared in a meaningful format. This need is a pressing one even if there are additional qualitative issues relating to social sustainability performance that do need to be presented in a descriptive way. In the social sustainability dimension of community involvement, little measurement is reported, indicating a further need for research into the topic. Additionally qualitative background information can yield valuable insights into achievements and future goals.

Integrated indicators: The integration of the three dimen- sions of sustainability is a challenge that only one of the sample companies has begun tackling in research and coordination. Against this background a number of questions need to be answered:

1 How to integrate indicators in practice?

1 How to measure integration?

- How to develop management incentives to promote sustainable performance within the firm?

I How to link sustainability, risk prevention and performance? There are various approaches that have been used to measure, monitor and assess a company's progress toward sustainability. None of these methods offers a clear universal tool that can be used either by all industries or by all companies within the same industry. The analysis of the sustainability metrics of the sample companies shows a large discrepancy on what and how the companies measure and report concerning their sustainability performance.

External incentives and the adoption of internal sustainable management practices seem to have a significant potential to transform companies into sustainable institutions.

Table 1: Metrics used by leader German companies

\begin{tabular}{|c|c|c|c|}
\hline Company & \multicolumn{2}{|c|}{ Environmental Sustainability Metrics } & Social Sustainability Metrics \\
\hline $\begin{array}{l}\text { Allianz } \\
\text { Sustainability Report } 2004\end{array}$ & \multicolumn{2}{|c|}{$\begin{array}{l}\text { \% of employees in environmental management } \\
\text { energy consumption (M)/employee/year) } \\
\text { total water consumption (Liters/employee/year) } \\
\text { emission of greenhouse gases (kg/employ/year) } \\
\text { waste (kg/employee/year) } \\
\text { paper consumption (kg/employee/year) } \\
\text { business travel (km/employee/year) }\end{array}$} & $\begin{array}{l}\text { Social Sustainability Metrics } \\
\text { employee total number } \\
\text { staff in training (number) } \\
\text { average participation of employees in education } \\
\text { measures (days) } \\
\text { fluctuation rate (\%) } \\
\text { \% Proportion of female employees in management } \\
\text { and executive positions }\end{array}$ \\
\hline $\begin{array}{l}\text { Axel Springer } \\
\text { Sustainability Report } 2003 \\
\text { Only available online }\end{array}$ & \multicolumn{2}{|c|}{$\begin{array}{l}\text { total material consumption } \\
\text { processing of material that is treated or untreated waste } \\
\text { from other sources } \\
\text { direct energy consumption by type } \\
\text { total water consumption } \\
\text { emission of greenhouse gases } \\
\text { emission of gases harmful to the ozone layer } \\
\text { emissions into the atmosphere } \\
\text { waste (quantity, type of depositing, incineration) } \\
\text { Significant quantities of spilled chemicals, oils and fuels } \\
\text { Acceptance of return of used products }\end{array}$} & $\begin{array}{l}\text { Jobs, classified by type and country } \\
\text { Average fluctuation and net change in employment } \\
\text { - Proportion of staff covered by industry-wide collective } \\
\text { tariff agreements } \\
\text { - Practice of documentation of industrial accidents and } \\
\text { illnesses } \\
\text { L Lost days/ absence rates due to injuries in industrial } \\
\text { accidents and work-related deaths } \\
\text { Average hours of training/further training per employee } \\
\text { (differentiated by staff categories) } \\
\text { aroportion of female/ male employees in management } \\
\text { and executive positions }\end{array}$ \\
\hline \multirow[t]{2}{*}{$\begin{array}{l}\text { Deutsche Telekom } \\
\text { HR and Sustainability } \\
\text { Report } 2004\end{array}$} & $\begin{array}{l}\text { refers to e- Earnings before } \\
\text { interest, tax, } \\
\text { amortization and } \\
\text { depreciation } \\
\text { Operating free cash flow } \\
\text { net income } \\
\text { net revenue } \\
\text { no. of sustainability indi- } \\
\text { ces/funds in German } \\
\text { speaking countries in } \\
\text { which shares are listed }\end{array}$ & $\begin{array}{l}\text { I energy consumption (GWh) } \\
\mathrm{CO}_{2} \text { emissions (relative to } \\
\text { energy consumption) } \\
\text { Water (\% recycled) } \\
\text { Wastewater (mill m3) } \\
\text { paper ( } 1000 \text { tons) } \\
\text { Annual Fleet Service } \mathrm{CO}_{2} \\
\text { emissions relative to mileage } \\
\text { Percentage of waste recycled }\end{array}$ & $\begin{array}{l}\text { Employee commitment } \\
\text { \% female employees (total/managerial positions) } \\
\% \text { of disabled persons } \\
\text { \% of } 25 \text { largest suppliers that fulfil social criteria } \\
\text { Trainee ratio } \\
\text { In-company further training expenses relative to total } \\
\text { personnel costs } \\
\% \text { of part-time employees } \\
\text { Health rate }\end{array}$ \\
\hline & Integrated indicators: & \multicolumn{2}{|c|}{$\begin{array}{l}\text { no. of services identified with potential to contribute to Sustainability } \\
\text { no. of measures implemented to promote GC } \\
\text { no. of telework jobs } \\
\text { internal online training programs } \\
\text { participants in x-online schemes to overcome digital divide }\end{array}$} \\
\hline
\end{tabular}


Table 1 cntd: Metrics used by leader German companies

\begin{tabular}{|c|c|c|}
\hline Company & Environmental Sustainability Metrics & Social Sustainability Metrics \\
\hline $\begin{array}{l}\text { RWE } \\
\text { Corporate Responsibility } \\
\text { Report } 2003\end{array}$ & $\begin{array}{l}\left.\text { CO } \mathrm{CO}_{2} \text { emissions (in } 1000 \mathrm{~m}^{3}\right) \\
\text { Water consumption }\left(1000 \mathrm{~m}^{3}\right) \\
\text { Waste }(1000 \mathrm{t} \text { ) } \\
\text { paper and glass recycled } \\
\text { Expenditure for environmental protection (mill } € \text { ) }\end{array}$ & $\begin{array}{l}\text { I employees total number } \\
\text { proportion of women } \\
\text { proportion of disabled } \\
\text { total number apprentices }\end{array}$ \\
\hline $\begin{array}{l}\text { Schering } \\
\text { Environmental Report } 2003\end{array}$ & $\begin{array}{l}\text { energy consumption (GWh) } \\
\mathrm{CO}_{2} \text { emissions (tons) } \\
\text { Water consumption (mill } \mathrm{m}^{3} \text { ) and } \\
\text { Wastewater (t COD burdens) } \\
\text { Waste (tons) } \\
\text { Environmental protection spending } \\
\text { input/output } \\
\text { transport modes (ship, airplane, truck/car) }\end{array}$ & $\begin{array}{l}\text { employee total number } \\
\text { accidents per mill hours } \\
\text { total number of apprentices } \\
\text { frequency of EHS training }\end{array}$ \\
\hline $\begin{array}{l}\text { Siemens } \\
\text { Corporate Responsibility } \\
\text { Report } 2003\end{array}$ & $\begin{array}{l}\text { - energy consumption (GWh) } \\
\mathrm{CO}_{2} \text { emissions (tons) } \\
\text { Water consumption (mill } \mathrm{m}^{3} \& \mathrm{l} / \mathrm{E} \text { ) } \\
\text { Wastewater (mill } \mathrm{m}^{3} \text { ) } \\
\text { Waste (tons \& } \mathrm{t} / \mathrm{E}) \\
\text { business travel (total } \mathrm{km} \text { ) } \\
\text { Environmental protection spending } \\
\text { (total and } € / \text { Employee) }\end{array}$ & $\begin{array}{l}\text { employee total number } \\
\text { proportion of women (total \& top management) } \\
\text { personnel cost total } \\
\text { number of apprentices } \\
\text { donations }\end{array}$ \\
\hline $\begin{array}{l}\text { Volkswagen } \\
\text { Environmental Report 2003/2004 }\end{array}$ & $\begin{array}{l}\text { - energy consumption (mill GWh) } \\
\mathrm{CO}_{2} \text { emissions (tons) } \\
\text { Water consumption }\left(\text { mill } \mathrm{m}^{3} \text { ) }\right. \\
\text { Wastewater (mill } \mathrm{m}^{3} \text { ) } \\
\text { Industrial and hazardous waste (tons) } \\
\text { Environmental protection spending (mill } € \text { ) } \\
\text { Recycling (tons) }\end{array}$ & $\begin{array}{l}\text { employee total number } \\
\text { proportion of women } \\
\text { proportion of apprentices } \\
\text { total no. of accidents }\end{array}$ \\
\hline
\end{tabular}

Source: Authors

Some major German companies have made significant progress in measuring economic performance. Examples of these companies include Allianz, Axel Springer, Deutsche Telekom, RWE, VW, Siemens and Schering. There are clear rules and a wide understanding of how to take the economic pulse of a company at any given time. The environmental performance of companies is measured mainly by assessing the externalities of the firm to society and environment. In other words by measuring the environmental footprint of the firm. The assessment of the environmental performance of companies is still very limited since it is mainly based on primary environmental impacts such as natural resource depletion, land degradation, pollution emissions, energy consumption and waste generation. Thus, it does not cover the long-term environmental impact of company operations.

The assessment of the social impact of companies seems a more difficult task and much less developed than the assessment of economic and environmental performance. Companies today tend to focus and report on their philanthropic initiatives and improved labor practices. Examples are reducing accidents at work, hiring more women and employing more people from different cultures. Although highly desirable, these practices do not reflect the expectations society has of the private sector when it comes to building a sustainable society.

\section{Literature}

CSR Europe/ Deloitte/ Euro Next: Investing in Responsible Business. The 2003 survey of European fund managers, financial analysts, and investor relations officers. 2003.

Jennings, P./ Vernon, R.: Addressing the Economic Bottom Line. In: Henri ques, A./ Richardson, J. (eds.): The Triple Bottom Line-Does It All Add Up? London 2004.

ISO: ISO prepares to launch development of standard on social responsibility. Press release January 2005. www.iso.org.

Schmidheiny, S.: Changing Course. Cambridge 1992.

Sywottek, C.: Macht's gut. In: brand eins, October 2004. www.brandeins.de. Székely, F./ Vollman, T./ Ebbinghaus, A.: Environmental Benchmarking. Becoming Green and Competitive. Cheltenham 1996.

Tanzil, D./ Ma, G./ Beloff, B.: Sustainability Metrics. Presentation, October 2003. 
(c) 20I0 Authors; licensee IÖW and oekom verlag. This is an article distributed under the terms of the Creative Commons Attribution Non-Commercial No Derivates License (http://creativecommons.org/licenses/by-nc-nd/3.o/), which permits unrestricted use, distribution, and reproduction in any medium, provided the original work is properly cited. 